\title{
Muscarinic M3 receptor stimulation increases cigarette smoke-induced IL-8 secretion by human airway smooth muscle
} cells

\author{
R. Gosens*, D. Rieks*, H. Meurs*, D.K. Ninaber", K.F. Rabe ${ }^{\#}$, J. Nanninga*, \\ S. Kolahian*, , A.J. Halayko ${ }^{+}$, P.S. Hiemstra ${ }^{\#}$ and S. Zuyderduyn\#
}

ABSTRACT: Acetylcholine is the primary parasympathetic neurotransmitter in the airways and is known to cause bronchoconstriction and mucus secretion. Recent findings suggest that acetylcholine also regulates aspects of remodelling and inflammation through its action on muscarinic receptors.

In the present study, we aimed to determine the effects of muscarinic receptor stimulation on cytokine production by human airway smooth muscle cells (primary and immortalised cell lines). The muscarinic receptor agonists carbachol and methacholine both induced modest effects on basal interleukin (IL)-8 and -6 secretion, whereas the secretion of RANTES, eotaxin, vascular endothelial growth factor-A and monocyte chemoattractant protein-1 was not affected. Secretion of IL-8 and -6 was only observed in immortalised airway smooth muscle cells that express muscarinic M3 receptors. In these cells, methacholine also significantly augmented IL-8 secretion in combination with cigarette smoke extract in a synergistic manner, whereas synergistic effects on IL-6 secretion were not significant.

Muscarinic M3 receptors were the primary subtype involved in augmenting cigarette smoke extract-induced IL-8 secretion, as only tiotropium bromide and muscarinic M3 receptor subtype selective antagonists abrogated the effects of methacholine.

Collectively, these results indicate that muscarinic M3 receptor stimulation augments cigarette smoke extract-induced cytokine production by airway smooth muscle. This interaction could be of importance in patients with chronic obstructive pulmonary disease.

KEYWORDS: Airway smooth muscle cells, cigarette smoke, human, interleukin-8, muscarinic receptors

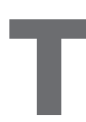
he role of acetylcholine as a neurotransmitter that regulates airway smooth muscle contraction and mucus secretion in the airways is well established, and is mediated through muscarinic receptors [1]. Acetylcholine is an important regulator of airway smooth muscle tone, especially in patients that suffer from chronic obstructive pulmonary disease (COPD), in whom cholinergic tone appears to be the primary reversible component of airflow obstruction. Therefore, anticholinergics are commonly used bronchodilators in COPD, and less frequently in asthma [2].
Recent findings show that the acetylcholine synthesising enzyme choline acetyl transferase (ChAT) is also expressed by non-neuronal sources such as the bronchial epithelium and inflammatory cells, including B- and T-lymphocytes, macrophages, mast cells, neutrophils and eosinophils [3-5]. These cells not only synthesise acetylcholine, but also express functional muscarinic receptors. A recent study showed that acetylcholine induces the release of neutrophil chemoattractants such as leukotriene $\mathrm{B}_{4}$ from sputum cells of COPD patients [6]. These results are consistent with studies demonstrating that alveolar macrophages exhibit
AFFILIATIONS

*Dept of Molecular Pharmacology, University of Groningen,

\#Dept of Pulmonology, Leiden University Medical Center, the Netherlands,

-Dept of Basic Sciences, Faculty of Veterinary Medicine, University of Tabriz, Tabriz, Iran, and

+Depts of Physiology and Internal Medicine, University of Manitoba, Winnipeg, MB, Canada.

CORRESPONDENCE

S. Zuyderduyn

Dept of Pulmonology, C3-P

Leiden University Medical Center Albinusdreef 2

2333 ZA Leiden

The Netherlands

E-mail: s.zuyderduyn@lumc.nl

Received:

March 192009

Accepted after revision:

May 122009

First published online:

May 212009 
neutrophil, eosinophil and monocyte chemotactic activities in response to acetylcholine $[7,8]$ and suggest that acetylcholine is a paracrine and/or autocrine mediator that regulates inflammatory processes.

Acetylcholine also triggers chemokine and cytokine release from structural cells that play a role in COPD pathogenesis. For example, bronchial epithelial cells exhibit neutrophil, eosinophil and monocyte chemotactic activity in response to acetylcholine [9, 10]. Since the synthesis of non-neuronal acetylcholine is relatively high in bronchial epithelial cells [11], these results implicate a role for acetylcholine (autocrine or paracrine) in initiating inflammatory responses. This contention is supported by animal studies that demonstrate protective effects of anticholinergics on inflammation induced by inhaled allergen [12] or inhaled diesel particles [13]. In addition, increased expression of ChAT has been reported in fibroblasts from active smokers and COPD patients [14]. Similar observations were reported in vitro in human lung fibroblasts (HFL-1) treated with cigarette smoke extract [14]. Whether acetylcholine regulates inflammatory responses in COPD is, however, largely unknown.

The airway smooth muscle cell is increasingly recognised as an important cellular source of pro-inflammatory cytokines and growth factors, including interleukins (IL)-6 and -8, monocyte chemoattractant protein (MCP)-1, vascular endothelial growth factor (VEGF) and others (see [15-17] for review) and it appears to play an important immunomodulatory role in airways diseases such as asthma and COPD. The immunomodulatory function of airway smooth muscle has mostly been studied in cell culture; these studies have revealed that Gprotein-coupled receptor agonists, growth factors, cytokines and extracellular matrix proteins can induce the release of significant amounts of pro-inflammatory cytokines [15-17]. In addition, airway smooth muscle cells exhibit IL-8 release in response to cigarette smoke extract, which is strongly augmented by cytokines such as tumour necrosis factor (TNF) $\alpha$ [18]. The regulatory role of acetylcholine in these synthetic airway smooth muscle cell responses is largely unknown. A study using bovine tracheal smooth muscle strips showed that stimulation with carbachol resulted in increased expression of IL-8, cyclooxygenase (COX)-1 and -2 at the mRNA level [19]. This study [19], together with the fact that airway smooth muscle expresses muscarinic M2 and M3 receptors in abundance, suggests a role for these receptors in release of mediators. Therefore airway smooth muscle may represent a primary target of acetylcholine released by nerve and other cell types in the airways.

Based on the above-mentioned observations, in the present study, we aimed to characterise the pro-inflammatory response of human airway smooth muscle cells induced by muscarinic receptor stimulation, and to investigate potential functional interactions with cigarette smoke extract. In addition, we aimed to investigate the role of muscarinic M2 and M3 receptor subtype(s) involved in these responses.

\section{MATERIALS AND METHODS Cell culture}

Human bronchial smooth muscle cell lines, immortalised by stable expression of human telomerase reverse transcriptase
(hTERT), were used for the experiments. The primary cultured human bronchial smooth muscle cells used to generate each cell line were prepared as previously described [20] from macroscopically healthy segments of second-to-fourth generation main bronchus obtained after lung resection surgery from patients with a diagnosis of adenocarcinoma. All procedures were approved by the Human Research Ethics Board of the University of Manitoba. As we have detailed previously [20], each cell line was thoroughly characterised to passage 10 and higher, and was shown to express a number of smooth muscle (sm) contractile phenotype marker proteins (e.g. sm-myosin heavy chain, sm- $\alpha$-actin and desmin). For all experiments, passage 10-25 myocytes grown on uncoated plastic dishes in Dulbecco's modified Eagle's medium (DMEM) supplemented with $50 \mathrm{U} \cdot \mathrm{mL}^{-1}$ streptomycin, $50 \mu \mathrm{g} \cdot \mathrm{mL}^{-1}$ penicillin and $10 \%$ $\mathrm{v} / \mathrm{v}$ fetal bovine serum (FBS) were used.

In selected experiments, primary human airway smooth muscle cells from two different commercial sources (Stratagene, La Jolla, and Clonetics, San Diego, CA, USA) were used. These cells were cultured in DMEM/F12 nutrient mixture supplemented with $25 \mathrm{mM}$ Hepes, $2.5 \mathrm{mM}$ L-glutamine, $1 \% \mathrm{v} / \mathrm{v}$ non-essential amino acids, 10\% v/v FBS (all from Invitrogen, Breda, The Netherlands) and antibiotics. Cells at passages 5-7 were used to perform experiments.

\section{Treatments}

Unless otherwise specified, cells were grown to confluence and serum-starved for 1 day in DMEM supplemented with antibiotics $\quad\left(50 \mathrm{U} \cdot \mathrm{mL}^{-1} \quad\right.$ streptomycin, $50 \mu \mathrm{g} \cdot \mathrm{mL}^{-1}$ penicillin, $1.5 \mu \mathrm{g} \cdot \mathrm{mL}^{-1}$ amphotericin B) and ITS $\left(5 \mu \mathrm{g} \cdot \mathrm{mL}^{-1}\right.$ insulin, $5 \mu \mathrm{g} \cdot \mathrm{mL}^{-1}$ transferrin and $5 \mathrm{ng} \cdot \mathrm{mL}^{-1}$ selenium) before each experiment. Cells were then subjected to different treatments for $24 \mathrm{~h}$ in DMEM supplemented with antibiotics. Muscarinic receptor antagonists (gallamine, 4-DAMP, DAU5884 and tiotropium) were added $30 \mathrm{~min}$ prior to the addition of agonists. Cigarette smoke extract was prepared by combusting two Kentucky 2R4F research cigarettes (filters removed; Lexington, KY, USA) using a peristaltic pump (Watson Marlow 323 E/D, Wilmington, MA, USA) and passing the smoke through $25 \mathrm{~mL}$ of FBS-free DMEM supplemented with antibiotics at a rate of $5 \mathrm{~min} \cdot$ cigarette $^{-1}$. The obtained solution was referred to as $100 \%$ strength.

\section{Multiplex cytokine assays}

Undiluted supernatants of airway smooth muscle cell cultures were analysed using the Bio-plex 200 and the Bio-plex human cytokine 27-plex assay (Bio-Rad, Veenendaal, The Netherlands) according to the manufacturer's instruction. The 27-plex assay kit contains beads conjugated with monoclonal antibodies specific for IL-1 $\beta$, IL-1ra, IL-2, -4, -5, -6, -7, -8, $-9,-10,-12,-13,-15$ and -17 , eotaxin, fibroblast growth factor, granulocyte colony-stimulating factor, granulocytemacrophage-colony-stimulating factor, interferon (IFN)- $\gamma$, interferon-inducible protein-10 (IP-10), MCP-1, macrophage inflammatory protein- $1 \alpha$ and $-1 \beta$, platelet-derived growth factor-BB, RANTES, TNF- $\alpha$ and VEGF. The detection limit was $\sim 10 \mathrm{pg} \cdot \mathrm{mL}^{-1}$ for all cytokines. Standard curves and the concentration of cytokines within samples were generated with the Bio-Plex Manager 4.1 software (Bio-Rad Laboratories). 


\section{Cytokine ELISA}

Cytokine levels were quantified in cell-free supernatants using ELISA, according to the manufacturer's instructions. The detection limit of the IL-8 ELISA was $1 \mathrm{pg} \cdot \mathrm{mL}^{-1}$ and $0.2 \mathrm{pg} \cdot \mathrm{mL}^{-1}$ for the IL-6 ELISA (both from Sanquin, Amsterdam, The Netherlands).

\section{PCR}

RNA was isolated using the Qiagen RNeasy Minikit (Qiagen, Valencia, CA, USA) in combination with the Qiagen RNaseFree DNase Set (Qiagen). The RNA concentration and purity were determined by measuring optical density measurements using the NanoDrop ND-1000 UV-Vis Spectrophotometer (Nanodrop Technologies, Wilmington, DE, USA). Reverse transcription of $500 \mathrm{ng}$ of total RNA was performed using $200 \mathrm{U}$ of Moloney murine leukaemia virus reverse transcriptase (Invitrogen), $0.5 \mathrm{mM}$ of dNTPs (Invitrogen), $0.5 \mu \mathrm{g}$ of oligo $(\mathrm{dT})_{15}$ primer (Promega, Madison, WI, USA), RNasin RNase inhibitor $40 \mathrm{U}$ (Promega), $10 \mathrm{mM}$ dithiothreitol (Invitrogen), $50 \mathrm{mM}$ Tris- $\mathrm{HCl}$ ( $\mathrm{pH} 8.3), 75 \mathrm{mM} \mathrm{KCl}$ and $3.0 \mathrm{mM} \mathrm{MgCl} 2$ in a total volume of $20 \mu \mathrm{L}$. PCR was performed at $95^{\circ} \mathrm{C}$ for $4 \mathrm{~min}$ followed by 25 or 35 cycles of $15-\mathrm{s}$ denaturing, 15-s annealing and 30-s amplification using $0.5 \mathrm{pmol}$ gene-specific primers (supplementary material table E1), nucleotide mix (Invitrogen) in a final concentration of $0.08 \mathrm{mM}$ each, $1 \mathrm{U}$ of GoTaq Flexi DNA polymerase (Promega), $5 \mu \mathrm{L}$ of $5 \times$ Green GoTaq Flexi reaction buffer (Promega) and different concentrations of $\mathrm{MgCl}_{2}$ in a final volume of $25 \mu \mathrm{L}$. $\beta$-actin was used as a housekeeping gene. Products were visualised using a $1.5 \%$ agarose gel containing ethidium bromide.

\section{Data analysis}

Values reported for all data are represented as mean $\pm \mathrm{SE}$, unless otherwise specified. The statistical significance of differences between means was determined by one-way Kruskal-Wallis ANOVA, followed by Dunn's multiple comparisons test. Differences were considered to be statistically significant when $\mathrm{p}<0.05$.

\section{RESULTS}

Muscarinic receptors induce IL-8 and IL-6 secretion from airway smooth muscle cell lines that express muscarinic M3 receptors

To evaluate the role of muscarinic receptors in the synthetic function of airway smooth muscle cells, we analysed supernatants of airway smooth muscle cells treated with carbachol for an array of secreted proteins using a multiplex cytokine assay. We used a mixture of pro-inflammatory cytokines (TNF- $\alpha$, IL-1 $\beta$ and IFN- $\gamma$ ) as a positive control for induction of cytokines, chemokines and growth factors and to normalise for heterogeneity in responses between cell lines. Using cells from one of the immortalised cell lines, we found that carbachol alone induced a modest increase in IL- 8 and IL- 6 release, compared with that induced by cytokine mixture, which induced release of several cytokines (e.g. IL-6), chemokines (including RANTES, eotaxin, MCP-1) and growth factors (e.g. VEGF-A) (fig. 1). A full list of mediators induced by the mixture of cytokines is listed in the online supplementary material (table E2). Little effect of carbachol exposure was seen in the primary airway smooth muscle cells from the commercial sources, whereas the cytokine mixture induced the same pattern of cytokine release that was observed for the immortalised airway smooth muscle cells (data not shown).

We verified our findings on IL-6 and -8 release using a sandwich ELISA. Carbachol $(0.01-100 \mu \mathrm{M})$ dose-dependently increased IL- 6 and -8 release in the immortalised cell line, with a greater increase in IL-6 compared with IL-8 (fig. 2a; donor 1). As in the Bio-plex assay, carbachol did not affect release of these factors in primary cultured cells (fig. $2 b$ and c; donors 2 and 3). As it has been shown that passage of primary cells in culture reduces the expression of muscarinic M3 receptors, we assessed the mRNA expression of muscarinic receptors (M1, M2 and M3 receptors). The immortalised cells expressed both M2 and M3 receptor mRNA in high amounts, whereas the primary cells from the commercial sources only expressed mRNA for M2 receptors (fig. 2). This difference between cell cultures suggested that $\mathrm{M} 3$ receptors could be involved in the carbachol-induced IL- 8 and -6 release. None of the airway smooth muscle cells we tested expressed the muscarinic M1 receptor.

\section{Muscarinic receptor stimulation augments IL-8 secretion induced by cigarette smoke extract}

We next evaluated the effects of muscarinic receptor stimulation on cytokine secretion in combination with cigarette smoke extract. Cigarette smoking is the main risk factor for COPD, and an aqueous extract of cigarette smoke induces the expression of several pro-inflammatory cytokines by cells that play an immunomodulatory role in COPD, including airway smooth muscle cells $[15,21]$. In view of our results examining the effects of muscarinic receptor ligation alone, and the differential expression pattern of muscarinic receptors between cell lines, we focused our next studies on the secretion of IL-6 and -8 using only the immortalised cell lines (which retain

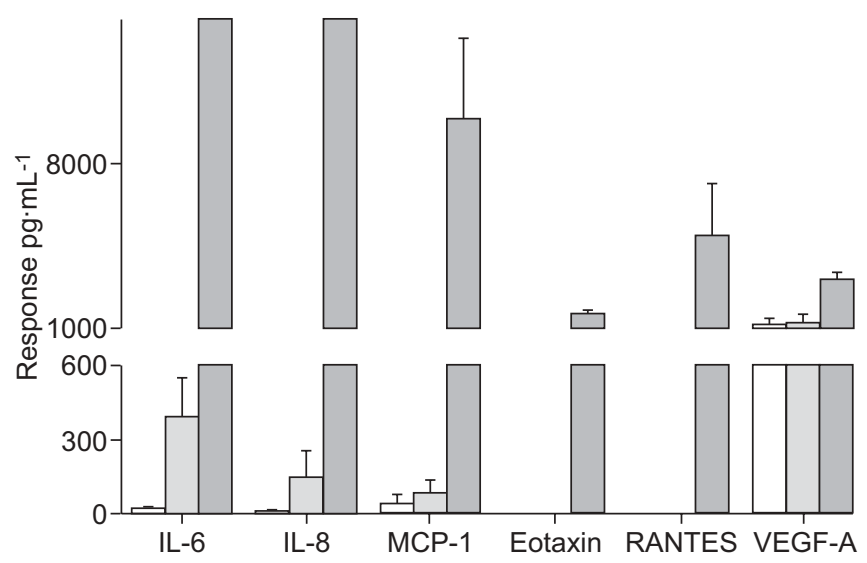

FIGURE 1. Synthetic responses of airway smooth muscle cells induced by carbachol and a mixture of tumour necrosis factor (TNF)- $\alpha$, interleukin (IL)-1 $\beta$ and interferon (IFN)- $\gamma$. Human airway smooth muscle cells (hTERT-immortalised) were grown to confluence and serum-deprived for 1 day in ITS $\left(5 \mu \mathrm{g} \cdot \mathrm{mL}^{-1}\right.$ insulin, $5 \mu \mathrm{g} \cdot \mathrm{mL}^{-1}$ transferrin and $5 \mathrm{ng} \cdot \mathrm{mL}^{-1}$ selenium)-supplemented media. Cells were subsequently treated with either $100 \mu \mathrm{M}$ of carbachol ( $\square$ ) or a mixture of TNF- $\alpha$, IL$1 \beta$ and IFN- $\gamma$ (all at $20 \mathrm{ng} \cdot \mathrm{mL}^{-1} ; \quad$ ) for $24 \mathrm{~h}$ in duplicate. Supernatants were harvested and analysed using the human cytokine 27-plex assay. Data shown are mean $\pm \mathrm{SD}$ of one experiment in duplicate. MCP-1: monocyte chemoattractant protein-1; VEGF-A: vascular endothelial growth factor-A. $\square$ : control. 


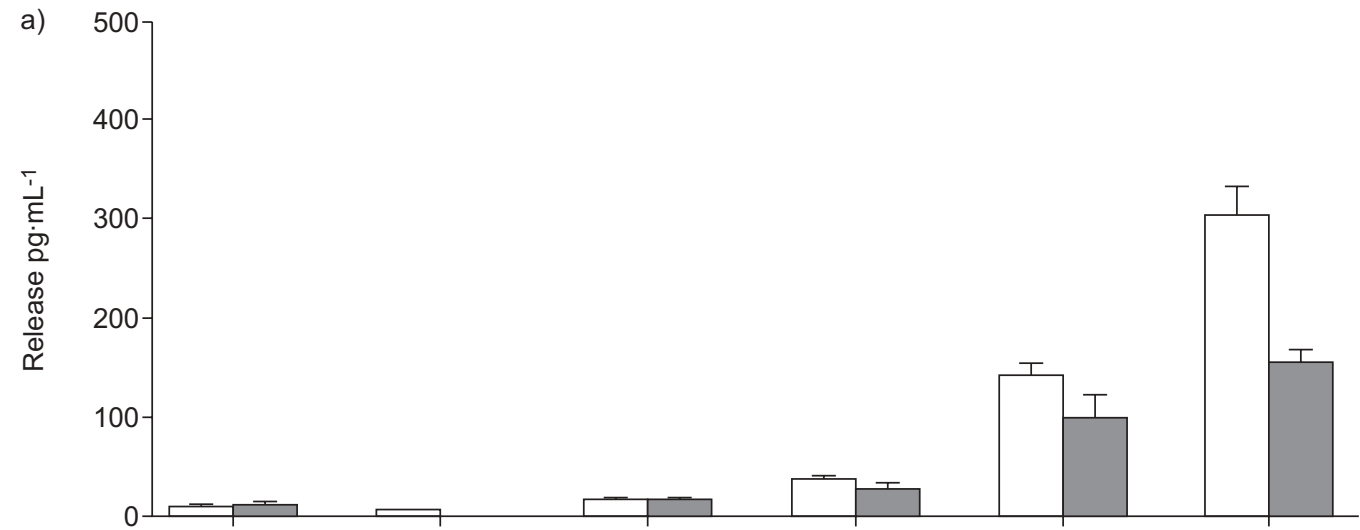

M1R

M2R

M3R

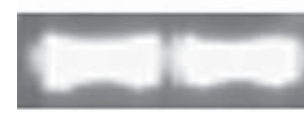

$\beta$-actin

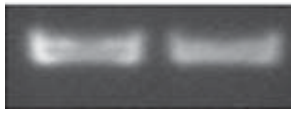

M1R

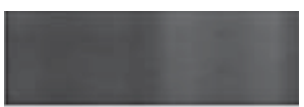

M2R

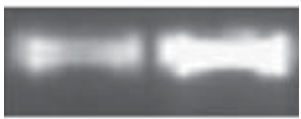

M3R

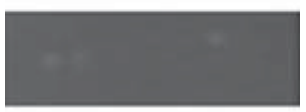

$\beta$-actin

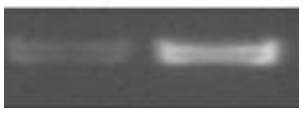

c)

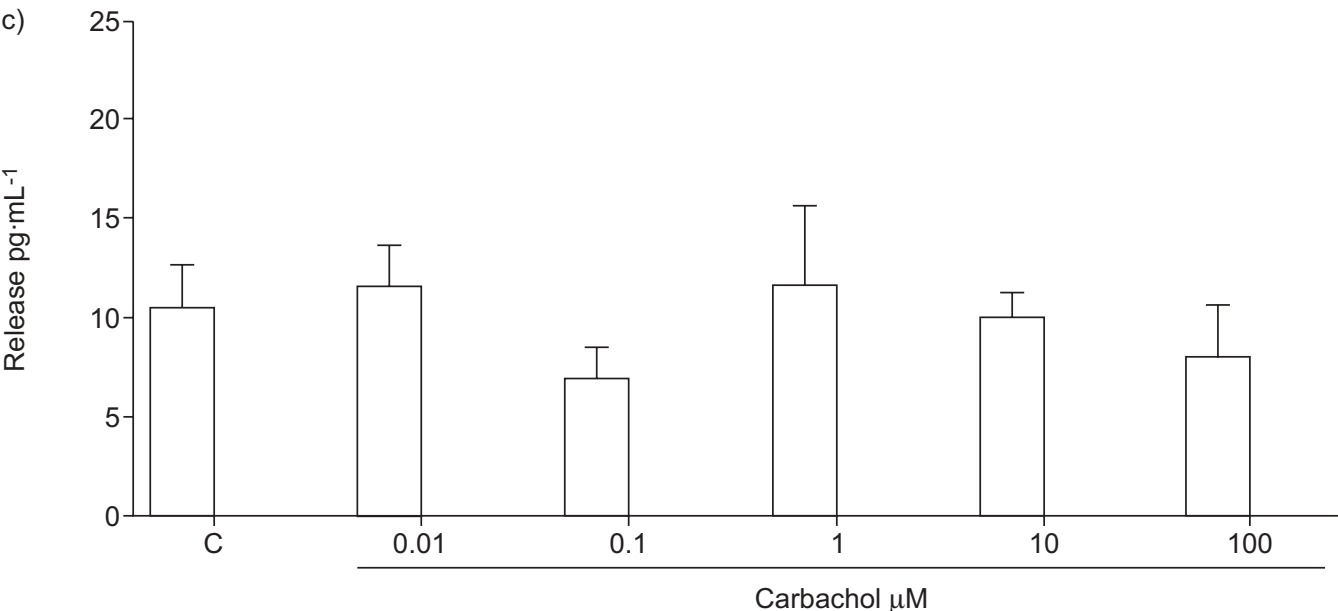

M1R

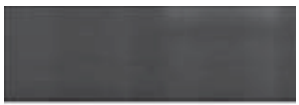

M2R

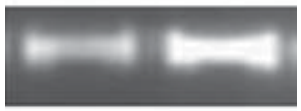

M3R

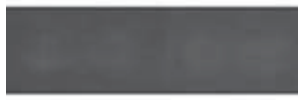

$\beta$-actin

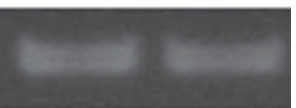

FIGURE 2. Carbachol induces an increase in interleukin (IL)-6 and -8 release in cells expressing the muscarinic M3 receptor (M3R) only. Human airway smooth muscle cells were grown to confluence and serum-deprived for 1 day in ITS $\left(5 \mu \mathrm{g} \cdot \mathrm{mL}^{-1}\right.$ insulin, $5 \mu \mathrm{g} \cdot \mathrm{mL}^{-1}$ transferrin and $5 \mathrm{ng} \cdot \mathrm{mL}^{-1}$ selenium)-supplemented media. Cells were subsequently treated in triplicate with increasing concentrations of carbachol as indicated. In addition, RNA of untreated cells was harvested. Supernatants were analysed for IL-6 and -8 release. Expression of muscarinic receptors was assessed using reverse transcriptase PCR. Data shown for IL-6 and -8 release are mean \pm SE of triplicates per experiment for cells from three different donors/sources: a) donor 1=immortalised airway smooth muscle cells, b) donor 2=commercial source (Strategene, La Jolla, CA, USA) and c) donor 3=commercial source Clonetics (San Diego, CA, USA). C: control. $\square$ : IL-6; 1 : IL-8.

muscarinic M3 receptor expression, see fig. 2). Moreover, our studies using these cells confirmed the functional expression of muscarinic $\mathrm{M} 3$ receptors, as ascertained by the mobilisation of intracellular $\mathrm{Ca}^{2+}$ in response to the muscarinic receptor agonists methacholine and acetylcholine, and by ligandbinding assays [22].
Cigarette smoke extract induced a profound induction of IL- 8 secretion that was concentration-dependent and maximal at the highest concentration tested (15\%) (fig. 3). The effects of higher concentrations were not evaluated as these induced significant cell death. Interestingly, cigarette smoke extract alone did not induce the secretion of IL- 6 , whereas methacholine alone did 
induce IL-6 (fig. 3), suggesting that its pro-inflammatory effects are quite specific. In addition to its ability to significantly increase IL-6 secretion, only a modest effect of methacholine was observed for IL-8 secretion in some experiments. The most profound induction of IL-8 secretion we observed occurred when cigarette smoke extract and methacholine were combined. For instance, although methacholine alone did not induce significant IL-8 secretion, it profoundly augmented the response induced by cigarette smoke extract, particularly at lower concentrations of cigarette smoke extract (fig. 3). No synergistic effects of methacholine and cigarette smoke extract on IL-6 secretion were observed. Further analysis of the interaction between methacholine and cigarette smoke extract indicated that the effects of methacholine were concentration dependent, with the most pronounced synergy observed at the highest concentration methacholine tested (10 $\mu \mathrm{M}$; fig. 4$)$. Since the synergistic effect on IL-8 secretion was highest for $10 \mu \mathrm{M}$ methacholine and 5\% cigarette smoke extract, we used these
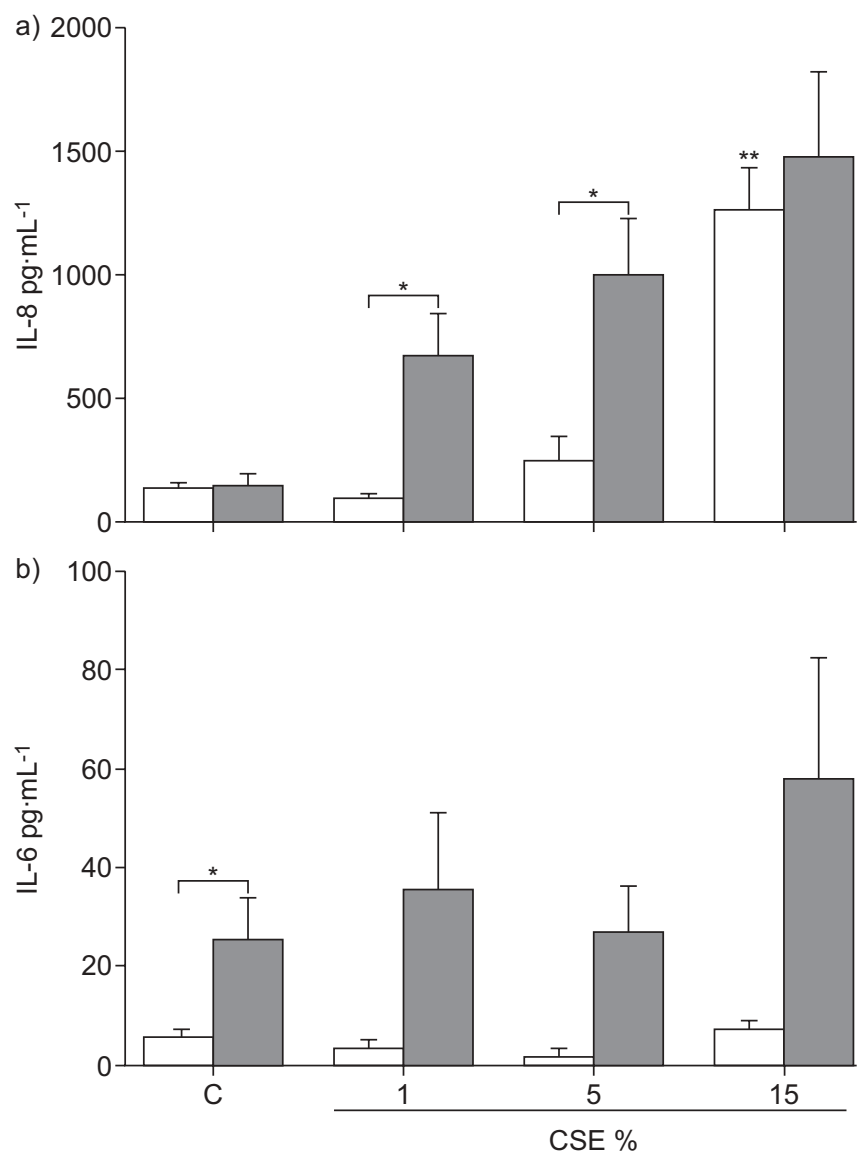

FIGURE 3. Methacholine augments cigarette smoke extract (CSE)-induced interleukin (IL)-8 secretion by airway smooth muscle. Human airway smooth muscle cells were grown to confluence and subsequently serum-deprived for 1 day in ITS ( $5 \mu \mathrm{g} \cdot \mathrm{mL}^{-1}$ insulin, $5 \mu \mathrm{g} \cdot \mathrm{mL}^{-1}$ transferrin and $5 \mathrm{ng} \cdot \mathrm{mL}^{-1}$ selenium)-supplemented media. Cells were then treated with increasing concentrations of CSE, in the absence $(\square)$ or presence $(\square)$ of methacholine $(10 \mu \mathrm{M})$, as indicated. Supernatants were then analysed for the presence of a) IL-8 or b) IL-6. Data shown are the mean \pm SE of four to six experiments, each performed in duplicate. C: control. $*: p<0.05 ; * *: p<0.01$. conditions in further experiments to assess the muscarinic receptors involved.

\section{Muscarinic M3 receptors augment IL-8 secretion induced by cigarette smoke extract}

Since our initial experiments suggested that the effects of muscarinic receptor stimulation on cytokine secretion were observed only in cells that express muscarinic M3 receptors, we next characterised the role of muscarinic receptor subtypes further. To this aim, we selected subtype selective muscarinic receptor antagonists DAU5884, 4-DAMP (M3 selective) and gallamine (M2 selective). The inhibitory effect of the clinically used muscarinic receptor antagonist tiotropium was also evaluated. M3-selective DAU5884 and 4-DAMP were applied in concentrations that occupy the majority (>99\%) of the muscarinic M3 receptor population with relatively modest ( $\sim 30 \%$ ) occupation of the muscarinic M2 subtype, whereas the concentration of the M2 selective gallamine was chosen to ensure no significant effects on M3 receptors [23-26]. Interestingly, both tiotropium and the M3-selective 4-DAMP and DAU5884 completely inhibited the synergistic effect of methacholine on cigarette smoke extract-induced IL-8 secretion, whereas the M2-selective gallamine had no significant effect (fig. 5). Responses induced by cigarette smoke extract alone were not affected by the treatment with the antagonists. These results confirm that the primary receptor subtype involved in the synergism between methacholine and cigarette smoke extract is the muscarinic M3 receptor.

\section{DISCUSSION}

The results from our study indicate that muscarinic receptor stimulation induces a pro-inflammatory response of airway smooth muscle cells, and that the response induced by

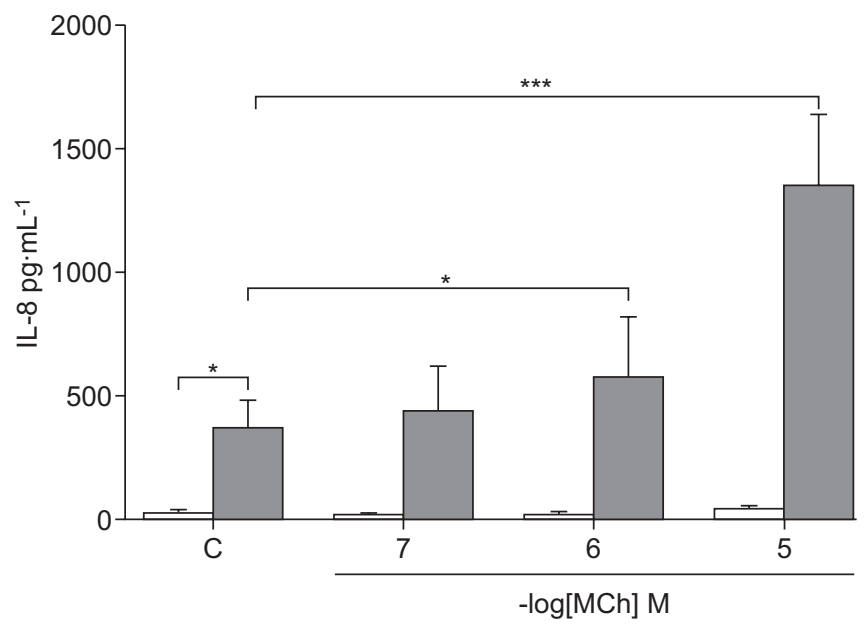

FIGURE 4. Potentiating effects of methacholine on cigarette smoke extractinduced interleukin (IL)-8 secretion are concentration dependent. Human airway smooth muscle cells were grown to confluence and subsequently serum-deprived for 1 day in ITS ( $5 \mu \mathrm{g} \cdot \mathrm{mL}^{-1}$ insulin, $5 \mu \mathrm{g} \cdot \mathrm{mL}^{-1}$ transferrin and $5 \mathrm{ng} \cdot \mathrm{mL}^{-1}$ selenium)supplemented media. Cells were then treated with increasing concentrations of methacholine (MCh), in the absence ( $\square$ ) or presence ( $\square$ ) of $5 \%$ cigarette smoke extract, as indicated. Supernatants were then analysed for the presence of IL-8. Data shown are the mean \pm SE of five experiments, each performed in duplicate C: control. *: $p<0.05 ;{ }^{* *}: p<0.001$ 


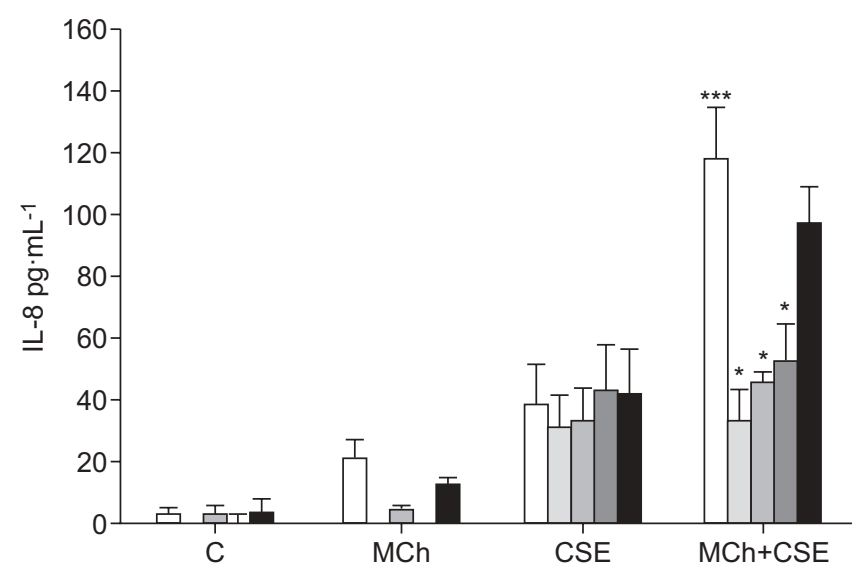

FIGURE 5. Potentiating effects of methacholine (MCh) on cigarette smoke extract (CSE)-induced interleukin (IL)-8 secretion are muscarinic M3-receptor dependent. Human airway smooth muscle cells were grown to confluence and subsequently serum-deprived for 1 day in ITS $\left(5 \mu \mathrm{g} \cdot \mathrm{mL}^{-1}\right.$ insulin, $5 \mu \mathrm{g} \cdot \mathrm{mL}^{-1}$ transferrin and $5 \mathrm{ng} \cdot \mathrm{mL}^{-1}$ selenium)-supplemented media. Cells were then treated with methacholine $(10 \mu \mathrm{M})$, CSE (5\%) or a combination of the two, in the absence or presence of muscarinic receptor antagonists (tiotropium, 4-DAMP, DAU5884 and gallamine) as indicated. Supernatants were then analysed for the presence of IL-8. Data shown are the mean \pm SE of four to six experiments, each performed in duplicate. C: without antagonist. $\square$ : control; $1:+10 \mathrm{nM}$ tiotropium; $\square:+100 \mathrm{nM}$ DAU5884; $\mathbf{\square}:+100$ nM 4-DAMP; $\mathbf{\square}:+10 \mu \mathrm{M}$ gallamine. ${ }^{*}: \mathrm{p}<0.05$ compared with cigarette smoke extract $+\mathrm{MCh}$ in the absence of antagonists; $* * *: p<0.001$ compared with control.

cigarette smoke extract is strongly enhanced. These results extend previous observations by others who have shown that muscarinic receptor stimulation can induce IL- 8 production by bronchial epithelial cells, and leukotriene $\mathrm{B}_{4}$ production by monocytes, macrophages and bronchial epithelial cells $[6,8-10$, 27]. Muscarinic receptor stimulation using carbachol was also previously shown to regulate pro-inflammatory gene transcription of IL-6 and -8 and COX-2 induced by mechanical stimulation of airway smooth muscle strips [19]. Our current findings confirm these studies and provide novel insights as we demonstrate a strong synergistic interaction with the response induced by cigarette smoke extract. Collectively, these findings indicate that muscarinic receptors are coupled to pro-inflammatory gene expression in several cell types involved in COPD pathogenesis.

The results from our study indicate that methacholine synergy with cigarette smoke extract is primarily dependent on the muscarinic M3 receptor subtype. Application of DAU5884 or 4DAMP in concentrations that are M3 selective almost completely inhibited the synergy between methacholine and cigarette smoke extract, whereas the antagonist gallamine, applied in concentrations that are M2 selective had no significant effect. It is clear therefore that the primary receptor subtype involved in synergy is the muscarinic M3 receptor. This is further confirmed by our studies indicating that airway smooth muscle cells that lost expression of functional M3 receptors in culture lack functional IL- 6 and -8 responses to carbachol. The M3-dependent nature of this effect is in line with findings reported for IL-8 production in epithelial cells [27], and complements our previous findings that indicate that the M3 receptor subtype is the primary receptor subtype involved in airway smooth muscle contraction and in cell proliferation induced by methacholine [23-25, 28]. Based on these findings, M3 receptor subtype selectivity would appear to be an advantageous property of muscarinic receptor antagonists, especially since inhibition of M2 autoreceptors on vagal nerve terminals is associated with enhanced acetylcholine release [3, 29]. Indeed, the "kinetic" muscarinic M3 selective properties of tiotropium have been viewed as beneficial and new muscarinic M3 receptor selective antagonists are currently under development [30-34]. Nonetheless, recent reports indicate that proliferative and pro-fibrotic responses of lung fibroblasts are mediated via muscarinic M2 receptors and pertussis toxin sensitive $G_{i / o}$ proteins $[35,36]$. Therefore it is clear that to clarify the benefits and negative aspects of muscarinic receptor subtype selectivity requires future study.

Our study was performed using both primary airway smooth muscle cells and several immortalised airway smooth muscle cell lines. The immortalised smooth muscle cells retained expression of the muscarinic M3 receptor and the capacity to regulate IL-8 secretion in concert with cigarette smoke, whereas the primary cells lost M3 receptor expression in culture as well as their capacity to produce IL- 8 in response to muscarinic receptor activation. The immortalised cells also retain the capacity to respond to contractile agonists (calcium signalling), the capacity for induction of contractile proteins, and the capacity to proliferate upon stimulation with growth factors $[20,37]$. These aspects make the immortalised cell lines a well-suited model with which to study the role of muscarinic M3 receptors in physiological responses of airway smooth muscle cells in vitro. However, translation of our results to intact organ systems, in vivo models and clinical studies is necessary to confirm the functional interaction of acetylcholine with cigarette smoke in patients.

Activation of the non-neuronal cholinergic system [38] in airway smooth muscle is unlikely to be of major functional importance to cigarette smoke-induced pro-inflammatory cytokine production, as we did not observe any effects of tiotropium or other muscarinic receptor antagonists on cells exposed to cigarette smoke extract alone. Nonetheless, in intact lungs, stimulation of muscarinic receptors, for example, by neuronal or inflammatory cell-derived acetylcholine, could augment the inflammatory response induced by smoking, suggesting that cigarette smoke extract could promote an immunomodulatory role for muscarinic receptors on airway smooth muscle cells, thereby potentiating its pro-inflammatory effects. Although increased airway smooth muscle mass is found in patients with COPD [39], the role of airway smooth muscle cells in the inflammatory process observed in COPD has not yet been extensively studied. Airway smooth muscle bundles in COPD patients are infiltrated by neutrophils and CD8+ T-cells [40, 41], suggesting that airway smooth muscle cells may actively recruit these cells. Also, in vitro studies have shown that airway smooth muscle cells produce IL-8 in response to many inflammatory mediators implicated in COPD, including TNF- $\alpha$ [42], IL-17 [43] and neutrophil products, such as LL-37 [44], bacteria [45] and cigarette smoke [18]. Combining cigarette smoke with TNF- $\alpha$ results in a synergistic increase in IL-8 release [46]. Our data also show 
that muscarinic receptor agonists can act in concert with cigarette smoke to induce the production of IL- 8 by airway smooth muscle cells, suggesting that these cells, in addition to epithelial cells and inflammatory cells, could play an important role in the inflammatory process involved in neutrophil recruitment and exacerbations of COPD. In addition, our findings may have implications for our understanding of muscarinic receptor function on airway smooth muscle cells in smoking asthmatics.

Clinical studies have demonstrated that anticholinergic agents, in particular the long-acting anticholinergic drug tiotropium bromide, have beneficial therapeutic effects in COPD patients that exceed their acute bronchodilatory effects. Several clinical studies suggest that tiotropium bromide may have beneficial effects on inflammation and/or remodelling in COPD, which is supported by several animal and cell culture studies that report effects of muscarinic receptors on cytokine production, cell proliferation, matrix protein production and airway remodelling (see references [3-5] for review). However, prior to our present study, reports that have directly investigated the interaction of muscarinic receptors with cigarette smokeinduced responses had been lacking. Our results provide important new insights in this area; however, studies that investigate the effects of muscarinic receptor antagonists in animal models of COPD are clearly needed.

In conclusion, the results from our study indicate that activation of muscarinic M3 receptors expressed by airway smooth muscle induces IL- 6 and -8 production and augments the pro-inflammatory cytokine response induced by cigarette smoke extract. These results imply a role for the airway cholinergic system in modulating cigarette smoke-induced inflammation that is of clear interest to COPD pathogenesis and treatment. Future studies are needed to investigate the role of this mechanism in COPD and to clarify the mechanisms involved.

\section{SUPPORT STATEMENT}

This work was supported by grants from Boehringer Ingelheim Pharma $\mathrm{GmbH}$, Biberach, Germany. R. Gosens is the recipient of a Veni fellowship (916.86.036) from the Dutch Organisation for Scientific Research (NWO), The Hague, The Netherlands. S. Kolahian is the recipient of a visiting scholarship from the Ministry of Science of the Islamic Republic of Iran, Tehran, Iran. A.J. Halayko is supported by the Canada Research Chairs Program and Canadian Institutes of Health Research, Ontario, Canada.

\section{STATEMENT OF INTEREST}

Statements of interest for R. Gosens, H. Meurs, K.F. Rabe, A.J. Halayko, P.S. Hiemstra and S. Zuyderduyn can be found at www.erj.ersjournals. $\mathrm{com} / \mathrm{misc} /$ statements.dtl

\section{ACKNOWLEDGEMENTS}

We are grateful to W.T. Gerthoffer (University of Nevada-Reno, Reno, NV, USA) for preparation of the hTERT cell lines used in the study.We thank D.A. Roelen (Dept of Immunohematology and Blood Transfusion, LUMC, Leiden, The Netherlands) for his help with the multiplex cytokine assays and J. Zaagsma (Dept of Molecular Pharmacology, University of Groningen, Groningen, The Netherlands) for insightful discussions. We thank H. Unruh (Section of Thoracic Surgery, University of Manitoba, Winnipeg, MB, Canada) for providing the lung resection surgery specimens used to generate the human bronchial smooth muscle cell lines.

\section{REFERENCES}

1 Belmonte KE. Cholinergic pathways in the lungs and anticholinergic therapy for chronic obstructive pulmonary disease. Proc Am Thorac Soc 2005; 2: 297-304.

2 Gross NJ, Skorodin MS. Role of the parasympathetic system in airway obstruction due to emphysema. N Engl J Med 1984; 311: 421-425.

3 Gosens R, Zaagsma J, Meurs H, et al. Muscarinic receptor signaling in the pathophysiology of asthma and COPD. Respir Res 2006; 7: 73.

4 Racke K, Matthiesen S. The airway cholinergic system: physiology and pharmacology. Pulm Pharmacol Ther 2004; 17: 181-198.

5 Racke K, Juergens UR, Matthiesen S. Control by cholinergic mechanisms. Eur J Pharmacol 2006; 533: 57-68.

6 Profita M, Giorgi RD, Sala A, et al. Muscarinic receptors, leukotriene B4 production and neutrophilic inflammation in COPD patients. Allergy 2005; 60: 1361-1369.

7 Buhling F, Lieder N, Kuhlmann UC, et al. Tiotropium suppresses acetylcholine-induced release of chemotactic mediators in vitro. Respir Med 2007; 101: 2386-2394.

8 Sato E, Koyama S, Okubo Y, et al. Acetylcholine stimulates alveolar macrophages to release inflammatory cell chemotactic activity. Am J Physiol 1998; 274: L970-L979.

9 Koyama S, Rennard SI, Robbins RA. Acetylcholine stimulates bronchial epithelial cells to release neutrophil and monocyte chemotactic activity. Am J Physiol 1992; 262: L466-L471.

10 Koyama S, Sato E, Nomura H, et al. Acetylcholine and substance P stimulate bronchial epithelial cells to release eosinophil chemotactic activity. J Appl Physiol 1998; 84: 1528-1534.

11 Proskocil BJ, Sekhon HS, Jia Y, et al. Acetylcholine is an autocrine or paracrine hormone synthesized and secreted by airway bronchial epithelial cells. Endocrinology 2004; 145: 2498-2506.

12 Bos IS, Gosens R, Zuidhof AB, et al. Inhibition of allergen-induced airway remodelling by tiotropium and budesonide: a comparison. Eur Respir J 2007; 30: 653-661.

13 McQueen DS, Donaldson K, Bond SM, et al. Bilateral vagotomy or atropine pre-treatment reduces experimental diesel-soot induced lung inflammation. Toxicol Appl Pharmacol 2007; 219: 62-71.

14 Profita M, Bonanno A, Siena L, et al. Smoke, choline acetyl transferase, muscarinic receptors and fibroblast proliferation in chronic obstructive pulmonary disease. J Pharmacol Exp Ther 2009; 329: 753-763.

15 Chung KF. The role of airway smooth muscle in the pathogenesis of airway wall remodeling in chronic obstructive pulmonary disease. Proc Am Thorac Soc 2005; 2: 347-354.

16 Tliba O, Panettieri Jr RA. Noncontractile functions of airway smooth muscle cells in asthma. Annu Rev Physiol 2009; 71: 509-535.

17 Zuyderduyn S, Sukkar MB, Fust A, et al. Treating asthma means treating airway smooth muscle cells. Eur Respir J 2008; 32: 265-274.

18 Oltmanns U, Chung KF, Walters M, et al. Cigarette smoke induces IL-8, but inhibits eotaxin and RANTES release from airway smooth muscle. Respir Res 2005; 6: 74.

19 Kanefsky J, Lenburg M, Hai CM. Cholinergic receptor and cyclic stretch-mediated inflammatory gene expression in intact ASM. Am J Respir Cell Mol Biol 2006; 34: 417-425.

20 Gosens R, Stelmack GL, Dueck G, et al. Role of caveolin-1 in p42/p44 MAP kinase activation and proliferation of human airway smooth muscle. Am J Physiol Lung Cell Mol Physiol 2006; 291: L523-L534.

21 Hardaker EL, Bacon AM, Carlson K, et al. Regulation of TNFalpha- and IFN-gamma-induced CXCL10 expression: participation of the airway smooth muscle in the pulmonary inflammatory response in chronic obstructive pulmonary disease. FASEB J 2004; 18: 191-193.

22 Gosens R, Stelmack GL, Dueck G, et al. Caveolae facilitate muscarinic receptor-mediated intracellular $\mathrm{Ca}^{2+}$ mobilization and contraction in airway smooth muscle. Am J Physiol Lung Cell Mol Physiol 2007; 293: L1406-L1418. 
23 Gosens R, Nelemans SA, Grootte Bromhaar MM, et al. Muscarinic M3-receptors mediate cholinergic synergism of mitogenesis in airway smooth muscle. Am J Respir Cell Mol Biol 2003; 28: 257-262.

24 Roffel AF, Elzinga CR, Van Amsterdam RG, et al. Muscarinic M2 receptors in bovine tracheal smooth muscle: discrepancies between binding and function. Eur J Pharmacol 1988; 153: 73-82.

25 Roffel AF, Elzinga CR, Zaagsma J. Muscarinic M3 receptors mediate contraction of human central and peripheral airway smooth muscle. Pulm Pharmacol 1990; 3: 47-51.

26 Roffel AF, Meurs H, Elzinga CR, et al. Characterization of the muscarinic receptor subtype involved in phosphoinositide metabolism in bovine tracheal smooth muscle. Br J Pharmacol 1990; 99 : 293-296.

27 Profita M, Bonanno A, Siena L, et al. Acetylcholine mediates the release of IL-8 in human bronchial epithelial cells by a NFkB/ERKdependent mechanism. Eur J Pharmacol 2008; 582: 145-153.

28 Watson N, Magnussen H, Rabe KF. Pharmacological characterization of the muscarinic receptor subtype mediating contraction of human peripheral airways. J Pharmacol Exp Ther 1995; 274: 1293-1297.

29 ten Berge RE, Zaagsma J, Roffel AF. Muscarinic inhibitory autoreceptors in different generations of human airways. Am J Respir Crit Care Med 1996; 154: 43-49.

30 Barnes PJ, Belvisi MG, Mak JC, et al. Tiotropium bromide (Ba 679 $\mathrm{BR})$, a novel long-acting muscarinic antagonist for the treatment of obstructive airways disease. Life Sci 1995; 56: 853-859.

31 Barnes PJ. The role of anticholinergics in chronic obstructive pulmonary disease. Am J Med 2004; 117: Suppl. 12A, 24S-32S.

32 Campbell SC. Clinical aspects of inhaled anticholinergic therapy. Respir Care 2000; 45: 864-867.

33 Disse B, Speck GA, Rominger KL, et al. Tiotropium (Spiriva): mechanistical considerations and clinical profile in obstructive lung disease. Life Sci 1999; 64: 457-464.

$34 \mathrm{Lu} \mathrm{S}$, Parekh DD, Kuznetsova O, et al. An oral selective M3 cholinergic receptor antagonist in COPD. Eur Respir J 2006; 28: 772-780

35 Haag S, Matthiesen S, Juergens UR, et al. Muscarinic receptors mediate stimulation of collagen synthesis in human lung fibroblasts. Eur Respir J 2008; 32: 555-562.
36 Matthiesen S, Bahulayan A, Kempkens S, et al. Muscarinic receptors mediate stimulation of human lung fibroblast proliferation. Am J Respir Cell Mol Biol 2006; 35: 621-627.

37 Tran T, McNeill KD, Gerthoffer WT, et al. Endogenous laminin is required for human airway smooth muscle cell maturation. Respir Res 2006; 7: 117.

38 Wessler I, Kirkpatrick CJ. Acetylcholine beyond neurons: the nonneuronal cholinergic system in humans. Br J Pharmacol 2008; 154: 1558-1571.

39 Hogg JC, Chu F, Utokaparch S, et al. The nature of small-airway obstruction in chronic obstructive pulmonary disease. $N$ Engl J Med 2004; 350: 2645-2653.

40 Slats AM, Janssen K, van SA, et al. Bronchial inflammation and airway responses to deep inspiration in asthma and chronic obstructive pulmonary disease. Am J Respir Crit Care Med 2007; 176: 121-128.

41 Baraldo S, Turato G, Badin C, et al. Neutrophilic infiltration within the airway smooth muscle in patients with COPD. Thorax 2004; 59: 308-312.

42 John $\mathrm{M}, \mathrm{Au} \mathrm{BT}$, Jose PJ, et al. Expression and release of interleukin-8 by human airway smooth muscle cells: inhibition by Th-2 cytokines and corticosteroids. Am J Respir Cell Mol Biol 1998; 18: 84-90.

43 Rahman MS, Yang J, Shan LY, et al. IL-17R activation of human airway smooth muscle cells induces CXCL-8 production via a transcriptional-dependent mechanism. Clin Immunol 2005; 115: 268-276.

44 Zuyderduyn S, Ninaber DK, Hiemstra PS, et al. The antimicrobial peptide LL-37 enhances IL-8 release by human airway smooth muscle cells. J Allergy Clin Immunol 2006; 117: 1328-1335.

45 Issa R, Sorrentino R, Sukkar MB, et al. Differential regulation of CCL-11/eotaxin-1 and CXCL-8/IL-8 by gram-positive and gramnegative bacteria in human airway smooth muscle cells. Respir Res 2008; 9: 30 .

46 Oltmanns U, Walters M, Sukkar M, et al. Fluticasone, but not salmeterol, reduces cigarette smoke-induced production of interleukin-8 in human airway smooth muscle. Pulm Pharmacol Ther 2008; 21: 292-297. 